\title{
Minority stress, experience of parenthood and child adjustment in lesbian families
}

\author{
H. M. W. Bos, F. van Balen \& \\ D. C. VAN DEN BOOM \\ Department of Education, Faculty of Social and Behavioural Sciences, University of \\ Amsterdam, The Netherlands
}

\author{
TH. G. M. SANDFORT \\ HIV Center for Clinical and Behavioural Studies, New York State Psychiatric Institute \\ and Columbia University, USA
}

\begin{abstract}
The aim of this study was to explore the relationship of minority stress with experiences of parenthood (e.g. parental stress and parental justification) and child adjustment in lesbian mother families. Three components of minority stress were examined, namely, experiences of rejection as a result of the non-traditional family situation, perceived stigma, and internalized homophobia. A total of 100 planned lesbian families (100 biological mothers and 100 social mothers) were involved in this study. Data were collected by means of a written questionnaire. The lesbian mothers in this sample generally described low levels of rejection, they perceived little stigmatization, and they also manifested low levels of internalized homophobia. However, minority stress was significantly related to experiences of parenthood. Lesbian mothers with more experiences of rejection experienced more parental stress, and appeared to defend their position as mother more strongly (e.g. parental justification). Furthermore, mothers with higher levels of perceived stigma and internalized homophobia felt significantly more often that they had to defend their position as mother. Finally, mothers who reported more experience of rejection were also more likely to report behaviour problems in their children. Our findings emphasize the importance of the effect of minority stress on the lives of lesbian mothers and their children.
\end{abstract}

\section{Introduction}

Research on two-mother families has mainly focused on the consequences for the child of living in a family with two mothers, compared to families with a mother and a father. In the literature two-mother families in which the child was born to the lesbian

Address for correspondence: H. M. W. Bos, Department of Education, Faculty of Social and Behavioural Sciences, Wibautstraat 4, 1090 GE Amsterdam, The Netherlands. Tel: +31 20525 1206; E-mail: H.M.W.Bos@uva.nl Received: 24 October 2003. Accepted: 9 January 2004

ISSN 0264-6838/print/ISSN 1469-672X/online/04/040000-14

(C) 2004 Society for Reproductive and Infant Psychology

DOI: $10.1080 / 02646830412331298350$

JRI (gamma) JRI48632.3d 10/9/04 18:53:21 Rev 7.51n/W (Jan 20 2003)

The Charlesworth Group, Huddersfield 01484517077 
relationship are characterized as 'planned lesbian mother families' (Flaks et al., 1995, p. 105). In this relatively new family type, the two lesbian mothers (the biological mother and the social mother) planned their children together, this in contrast to lesbian families where children were born in a formerly heterosexual relationship. Existing research considers planned lesbian families primarily as a homogenous group. There are, however, important differences between planned lesbian families. Heterogeneity might, for instance, result from experiences lesbian mothers encounter with negative attitudes regarding their non-traditional family situation, and one's own attitude toward being lesbian. Such experiences can be assessed as stressors and have been defined as minority stress (Brooks, 1981; DiPlacido, 1998; Meyer, 1995, $2003 a, b)$. The aim of the present inquiry is to examine the relationship of minority stress with experiences of parenthood and child adjustment, among planned lesbian families.

Studies that considered planned lesbian families as a homogenous group have revealed no differences in child outcomes such as social competence, behavioural adjustment, and gender identity between children in lesbian and heterosexual families (e.g. Brewaeys et al., 1997; Golombok et al., 2003). The few studies that focused on parenting behaviour found indications that the non-biological mothers (e.g. social mothers) in planned lesbian families have a higher quality of parent-child interaction (Brewaeys, et al., 1997; Golombok et al., 1997) and parenting awareness skills (Flaks, et al., 1995) than do fathers in heterosexual families. Furthermore, within the lesbian families there was no difference between the biological mother and the social mother in quality of parent-child interaction (Brewaeys et al., 1997).

Little is yet known, for example, about sources of differences within lesbian families. Patterson (1995) found that when lesbian mothers shared the labour involved in childcare more evenly they reported a greater sense of well-being of their children. Another study reported that lesbian mothers who described their own psychological adjustment and self-esteem in positive terms were also more likely to report that their children were developing well (Patterson, 2001). However, research on diversity in families with lesbian parents and potential effects of such diversity on children is sparse. Nothing is known about the influence of minority stress on experiences of lesbian mothers.

Contextual sources of stress are major determinants of parenting, and these stressors can also both directly and indirectly influence children's adjustment. Research on diversity within heterosexual families has typically involved assessment of the adverse impact of difficult life circumstances such as low SES (e.g. Werner \& Smith, 1982), single parenting (Weinraub \& Wolf, 1983) and major negative life changes (Crnic et al., 1983). In sum, these studies found that parents with greater stress are less satisfied with their parenting, and greater stress is associated with lower child adjustment. Research further suggests that daily hassles, as appraised by the individual parent, are important predictors in parental stress and child outcomes (Österber \& Hagekull, 2000). In everyday life, mothers in lesbian families experience stigmatization and negative events related to their sexual orientation or non-traditional lifestyle, this in contrast to parents in heterosexual families. These experiences can be seen as important daily stressors for lesbian mothers, and because its potential negative effects it should be studied with priority.

Minority stress can be distinguished into several dimensions, such as actual negative experiences, expectations of rejection and discrimination, and internalized homophobia. Researchers have shown that lesbians and gay men are frequently 
exposed to prejudice events, including antigay/lesbian violence, discrimination, subtle forms of exclusion, and confrontation with negative attitudes regarding their nontraditional lifestyle (De Graaf \& Sandfort, 2000; Mays \& Cochran, 2001; Sandfort et al., in press). In addition to negative experiences that gay men and lesbian women experience in general, lesbian mothers have to deal with less favourable attitudes towards lesbian motherhood. In the Netherlands, where the present study is conducted, public opinion holds that a traditional family (i.e. family headed by a heterosexual couple) is the ideal environment to raise children-in contrast to a lesbian or gay family (van der Avort et al., 1996) - and dominant public opinion is not in favour of equal rights for lesbians when it comes to adopting children (van de Meerendonk \& Scheepers, in press). King and Black (1999) show that college students in the US expect that children of lesbian mothers have more behaviour problems than other children. Lesbian mothers learn to anticipate such negative attitudes by perceiving that other people in society do not really accept them and do not want to make contact with them. As a consequence, lesbians and gay men might think that society in general and specifically heterosexual people disrespect them because of their non-traditional lifestyle. To characterize these expectations of negative treatment, the term perceived stigma has been used (Herek \& Glunt, 1995; Meyer, 1995; Ross \& Rosser, 1996).

Long before lesbian women begin to realize their same-sex feelings, some have internalized societal antihomosexual attitudes (Shildo, 1994). This is called internalized homophobia, and represents a form of stress that is internal. Even in the absence of negative events, and even if one's minority status is successfully concealed, lesbians may be harmed by directing negative social values towards the self (Meyer, 2003a,b). Internalized homophobia can been seen as the homosexual opposite of self-esteem (Sandfort, 2000). Internalized homophobia consists of negative attitudes towards one's own homosexuality, as well as negative attitudes toward other homosexual persons (Shidlo, 1994; Szymanski et al., 2001).

The influence of minority stress on lesbian women and gay men has been examined in various studies. Several studies in the US and also in the Netherlands demonstrated a relationship between homo-negative experiences and adverse psychological health status (Sandfort \& Bos, 2000; Sandfort et al., in press; Waldo, 1999). In the workplace, for example, lesbian women who reported more rejection attributed to their homosexuality were less satisfied with their job (Sandfort et al., in press). The internalization of negative attitudes towards lesbian women and gay men has been found to be related to an array of mental health problems, including depression, alcoholism, and sexual dysfunction (see for review: Meyer, 2003). Lesbian families, however, have not previously been examined from the perspective of minority stress.

In the present study we examined the extent to which lesbian mothers experience minority stress. We also tested various hypotheses regarding the associations between minority stress, and experiences of parenthood and child adjustment. Our hypotheses were based on the idea that being a member of a differently valued minority group negatively affects the lives of the members of that group (Goffman, 1963) and on prior research about the influence of minority stress on the lives of lesbians. We hypothesized that lesbian mothers who experience more rejection and have higher levels of perceived stigma and internalized homophobia would experience parenthood as more stressful. These mothers also feel a stronger need to justify the quality of their 
parenthood. It was further hypothesized that children with lesbian mothers who experience more minority stress would be less well adjusted.

\section{Method}

Participants

Eligibility and recruitment of families. Lesbian families were considered eligible to participate in this study if the children were raised in two-mother lesbian families from birth. One of the children in the families had to be between 4 and 8 years old, and with respect to this child (i.e. target child) parental experience of parenthood and child adjustment is examined in the present study. In cases that there were more children between 4 and 8 years old, one of them was randomly picked out as target child by the researchers of this study.

Recruitment was done using four different strategies. We used the patients' files of the Medical Centre for Birth Control (MCBC), a centre providing assisted reproductive services to clients regardless of sexual orientation or having a relationship. In addition families were recruited with the help of the largest interest group for gay and lesbian parents. Furthermore, lesbian families were selected with the help of individuals with expertise in the area of gay and lesbian parenting. We also placed an advertisement in a lesbian magazine.

A letter of invitation was sent to 178 lesbian families. These families were selected because they met our criteria for participation. Of the 178 lesbian families contacted, 43 came from the MCBC, 60 from the interest group and 75 from experts in the area of gay and lesbian parenting. The total response rate was $99(55.6 \%)$, for the medical centre $18(41.9 \%)$, for the interest group $47(78.3 \%)$ and for the experts $34(45.3 \%)$. One family responded to the advertisement.

Participating families. A total of 100 two-mother families took part in the study. The biological mother of the target child in this study (e.g. the child that the mother kept in mind when she was answering the questionnaire) was designated as biological mother, and the other mother was designated as social mother.

Social mothers were older than biological mothers, although the difference was not significant (biological mothers: mean age $40.80, \mathrm{SD}=3.22$; social mothers: mean age 42.10, SD =5.90). Most biological mothers and social mothers were well educated (e.g. $75.5 \%$ of all mothers studied at a higher professional or academic level), and both mothers did not differ significantly from each other on educational level. The age at which biological and social mothers openly identified themselves as a lesbian (e.g. coming out) was $21.43(\mathrm{SD}=4.86)$ and $21.08(\mathrm{SD}=5.30)$, respectively. Biological and social mothers did not differ significantly from each other on this aspect. The lesbian couples had been together for an average of 14.9 years $(\mathrm{SD}=3.87)$. Most families (91\%) lived in an urban environment. The mean number of children in the families was $2.0(\mathrm{SD}=0.48)$. In each family, the target child was between 4 and 8 years of age $(M=5.8 ; S D=1.37)$; there were 48 girls and 52 boys.

\section{Materials}

Participants completed a written questionnaire that contained items on minority stress, experience of parenthood, and child adjustment. Both parents completed the 
questionnaire independently. Almost all variables were measured with scales, most of which had been used in other studies or were derived from scales successfully used by others. Standardized instruments with good psychometric properties were used.

Minority stress. The occurrence of rejection was assessed with a seven-item scale, based on the 'Leidse Mobbing Schaal' (LEMS; Hubert, 1996) and the Leymann Inventory of Psychological Terrorization (LIPT; Leymann, 1990). The LEMS and LIPT are two very large scales that measure experience of rejection at work. Because the length of these scales, we had to reduce the number of items and decided to select those items from these scales that specifically referred to ridiculing, marginalizing, or exclusion. Furthermore, we reformulated the selected items in such a way that they applied to experiences from parents with rejection in the social environment. Examples of items are: 'People called you names in relation to being a lesbian mother' and 'People asked annoying questions about your nontraditional family situation'. Respondents were asked to indicate on a 3-point scale ( $1=$ never and $3=$ regularly) how frequently the various forms of rejection had occurred in the previous year. Cronbach's alpha for rejection was good $(\alpha=0.72)$.

The 'Samen of Apart' questionnaire (SAP; Sandfort, 1997), a Dutch questionnaire about how lesbian and gay men think about being gay or lesbian, was used to measure perceived stigma and internalized homophobia. This assessment was develop by Sandfort (1997) and derived from existing instruments (Herek \& Glunt, 1995; Herek et al., 1997; Ross \& Rosser, 1996). In several studies (Bos \& Sandfort, 1999; Sandfort, 1997) the validity and internal consistency of these scales studies were judged as good. With respect to perceived stigma, assessment of expected social stigma and assumptions about heterosexual's attitudes towards homosexuality (i.e. assumed heterosexuals' attitudes) were measured. Examples of statements are 'Repression of homosexuality still occurs, even in the Netherlands' (expected social stigma) and 'Most straight people disapprove off homosexuality' (assumed heterosexuals' attitudes). In the present study Cronbach's alpha for expected social stigma was good ( $\alpha=0.77$; four items) and Cronbach's alpha for assumed heterosexuals' attitudes was sufficient $(\alpha=0.69$; six items).

The internalized homophobia (IHP) scale includes negative attitudes and feelings against one's own homosexuality as well as negative attitudes and feelings against other lesbians and gay men (Nungesser, 1983; Shildo, 1994; Szymanski, Chung \& Balsam, 2001). In the present study both forms of IHP were assessed. The scale that measured negative attitudes toward one's own homosexuality (IHP directed to the self) consisted of five items. Respondents had to indicate on a 5-point scale their agreement with the statement, ranging from 1 (fully disagree) to 5 (fully agree). Examples of items are 'Because I am a lesbian, I cannot really be myself', and 'I rather would not be lesbian'. The alpha for this scale was in this study 0.67 . The scale that measured negative attitudes towards other lesbians and gay men (IHP directed to others) consist of six items, for example: 'When I see certain lesbians on television, I don't want to belong to them' ( $1=$ fully disagree to $5=$ fully agree). The reliability of this scale was 0.73 .

Experiences of parenthood. The Nijmegen questionnaire regarding child-rearing circumstances (Nijmeegse vragenlijst voor de opvoedingssituatie NVOS; Robbroeckx $\&$ Wels, 1989) for the measurement of family stress was used to measure parental 
stress. Two dimensions were selected: parental burden (feeling burdened by the child) and parental competence (being able to handle the child). Examples of statements are 'Others (my partner) get too little attention because of my child' (parental burden) and 'I feel I'm slowly losing grip on my child' (parental competence). The items of both scales have response categories ranging from 1 (fully disagree) to 5 (fully agree). Wels and Robbroeckx (1991) have shown that the validity, internal consistency and stability of these subscales is good. Cronbach's alpha for parental burden was good $(\alpha=0.82)$ and for parental competence just sufficient $(\alpha=0.50)$.

Small qualitative studies about lesbian motherhood (Kaese \& Gillespie, 1999; Morningstar, 1999; Rothuizen, 2001; Seyda \& Herrera, 1998; Slater, 1999; Warmerdam \& Gort, 1998) showed that lesbian mother frequently reported that they feel pressure to justify the quality of their parenthood toward other people in their social environment. Because a scale to measure these feelings of parental justification was not available, we developed a one to assess these feelings. The scale consists of four items (for example: 'In anticipation of negative reactions form others, I give my children more attention than other parents do'). Each item is scored on a 6-point scale, ranging from 1 (fully disagree) to 6 (fully agree). Cronbach's alpha for this scale was 0.68 .

Child adjustment. Children's emotional/behavioural problems were used as indices of children's functioning and were assessed by using a Dutch translation of the Child Behaviour Checklist for age's 4-18 years (CBCL/4-18; Achenbach, 1991; Verhulst et al., 1996). The CBCL is a widely used and well-validated instrument for assessment of children's emotional/behavioural problems on the basis of the reports of their parents. The CBCL includes 118 behaviour problem items, and each is scored ' 0 ' if not true, ' 1 ' if somewhat true, and ' 2 ' if very true of their child. The emotional/behavioural problems consists of two broadband scales (namely, internalizing, and externalizing), and a total behaviour problem scale. The CBCL also includes items on social competence, although Verhulst and his colleagues (1996) showed that this scale has limited reliability for children younger than 6 years old. Therefore, the social competence scale was not used in this study. The alphas for the internalizing, externalizing and total behaviour scale were $0.78,0.87$, and 0.89 , respectively.

\section{Results}

\section{Descriptive statistics}

Table 1 presents the means and standard deviations of biological and social mothers scores on the different dimensions of minority stress, experiences of parenthood, and child adjustment. To examine if biological mothers and social mothers differ on the studied variables paired $t$-test were carried out. Table 1 also presents the results of these paired $t$-test.

Minority stress. Biological mothers and social mothers did not differ significantly from each other on actual negative experiences. Nor were significant differences obtained between biological mothers and social mothers on expected social stigma 
Table 1. Minority stress, parental experiences of parenthood, and emotional/behavioural adjustment of children (mean and standard deviations) for biological mothers and social mothers.

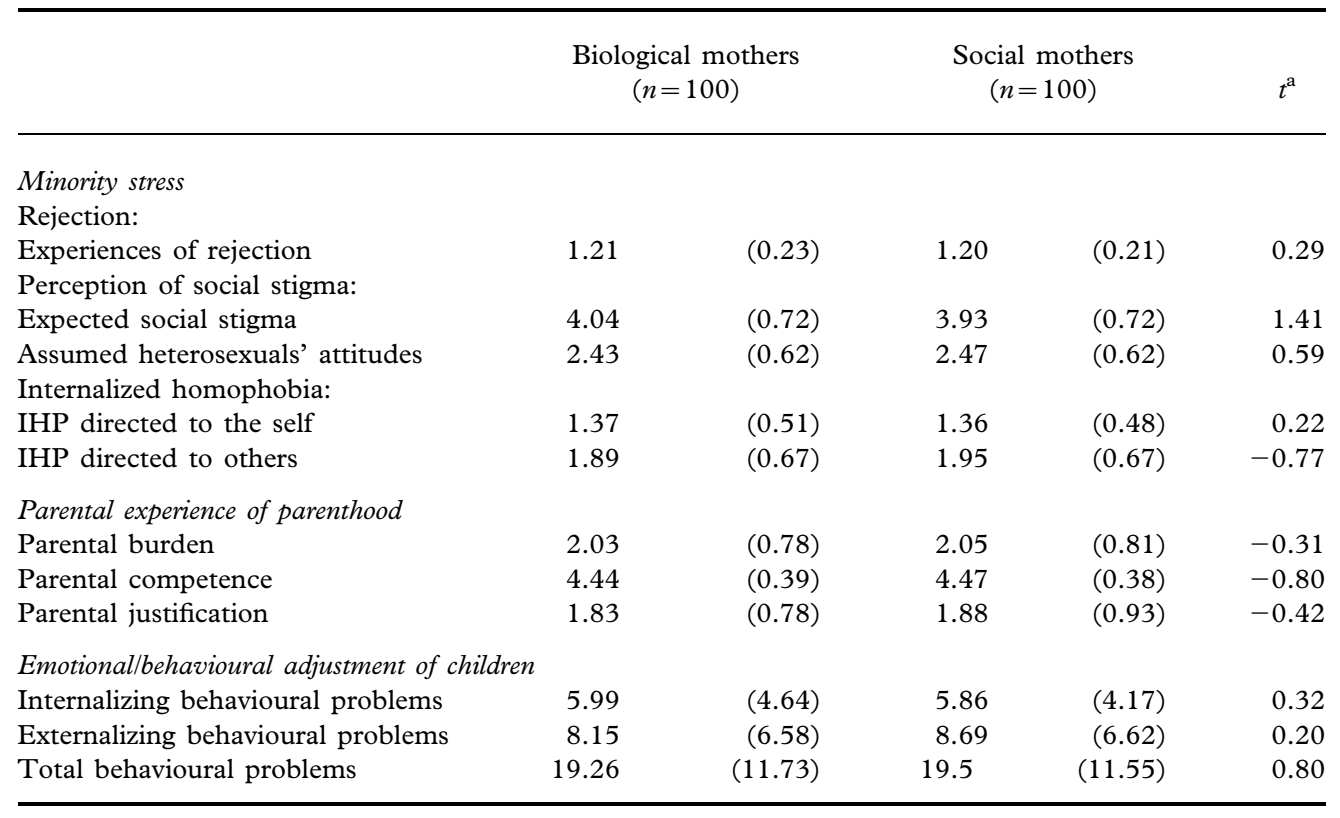

${ }^{\text {a }}$ Paired $t$ - test.

and assumed heterosexuals' attitudes. With respect to negative attitudes toward one's own homosexuality and negative attitudes against other lesbians and gay men, biological mothers and social mothers also did not differ significantly from each other.

The most frequently reported form of rejection was that other people asked annoying questions that were related to the lifestyle of the lesbian mothers (see Figure 1). Sixty-eight percent of the biological mothers and $72 \%$ of the social mothers reported this. Another frequently reported experience was that other people gossiped about non-traditional family lifestyle of the respondents $(27.3 \%$ of the biological mothers and $32.7 \%$ of the social mothers). Somewhat less frequently reported experiences were disapproving comments related to their family situation (13\% of the biological mothers and $12.1 \%$ of the social mothers) and exclusion by other people (12\% of the biological mothers and $9.1 \%$ of the social mothers). Smaller proportions of respondents reported other forms of experiences with rejection. Biological and social mothers did not differ significantly from each other on the different forms of rejection.

Experience of parenthood. There were no significant differences between biological mothers and social mothers on parental competence, parental burden, and parental justification.

The emotional/behavioural adjustment of children. On average children in the present sample were well adjusted. There were no significant differences between the 


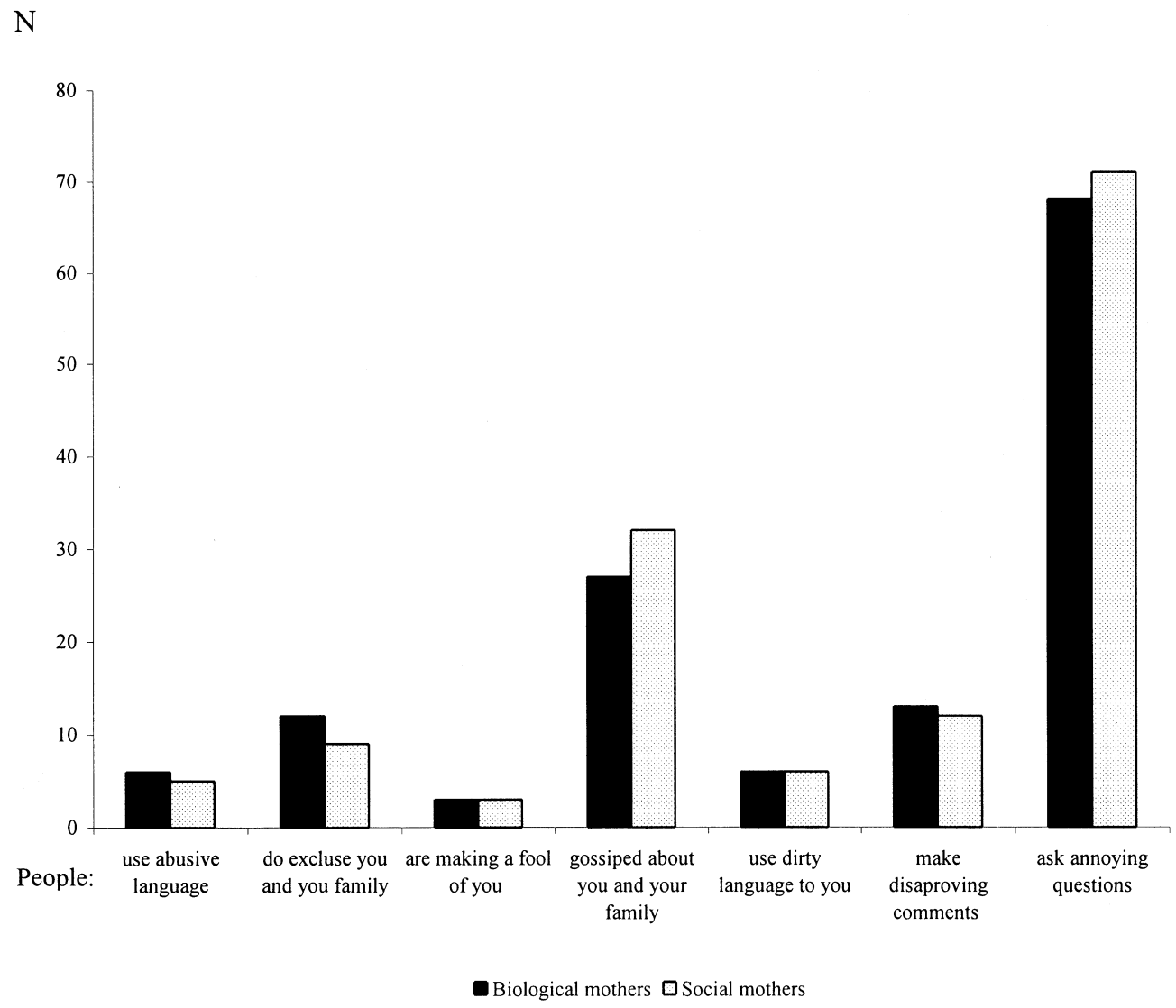

Figure 1. Lesbian mothers' (biological and social) experiences with various forms of rejection.

biological mothers' report of the child emotional/behavioural adjustment functioning and the social mothers' report.

\section{Minority stress, experience of parenthood, and child adjustment}

To access the relationship of the different dimensions of minority stress with parental experience of parenthood and child adjustment, correlation coefficients (Pearson's product-moment correlation $r$ ) were calculated. Correlations were conducted on the total group of lesbian mothers, because biological mothers and social mothers did not differ significantly from each other on minority stress, experiences of parenthood, and child adjustment.

Minority stress, and experience of parenthood. As shown in Table 2, almost all dimensions of minority stress were significantly correlated with parental justification. Lesbian mothers who reported more experiences with rejection felt more often pressed to justify the quality of their motherhood towards others. Furthermore, lesbian mothers who more strongly agreed that heterosexuals think negatively about homosexuality also felt they had to justify the quality of their 
Table 2. Pearson's product-moment correlation $\mathrm{r}$ between minority stress, parental experience of parenthood, and child adjustment.

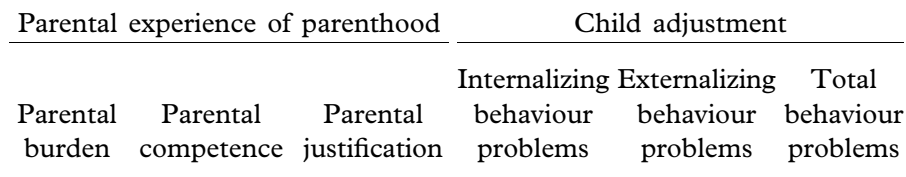

\begin{tabular}{lrrlrrr}
\hline & & & & & & \\
Experiences of rejection & $0.15^{\star \star}$ & $-0.13^{\star \star}$ & $0.23^{\star \star \star}$ & $0.15^{\star \star}$ & $0.18^{\star \star \star}$ & $0.21^{\star \star \star}$ \\
Expected social stigma & 0.04 & -0.04 & 0.09 & 0.01 & -0.02 & 0.01 \\
Assumed heterosexuals' attitudes & -0.01 & -0.08 & $0.24^{\star \star \star}$ & 0.10 & 0.03 & 0.09 \\
IHP directed to the self & 0.08 & -0.09 & $0.22^{\star \star \star}$ & 0.03 & -0.04 & -0.01 \\
IHP directed to others & -0.06 & 0.04 & $0.14^{\star}$ & -0.05 & 0.01 & -0.01 \\
\hline
\end{tabular}

${ }^{\star \star \star} p<0.001,{ }^{\star \star} p<0.01,{ }^{\star} p<0.05$.

motherhood more often. Mothers with high levels of negative feelings toward their own homosexuality (e.g. IHP towards the self) and mothers with high levels of negative feelings towards other lesbian women and gay men also felt that they had to justify the quality of their parenthood more often.

In order to examine the unique contribution of the dimensions of minority stress on parental justification, we conducted a multiple regression analyses. In his analyses, parental justification was the dependent variable. Those dimensions of minority stress related to parental justification were used as predictors, namely: rejection, assumed heterosexuals' attitudes, IHP directed to others, and IHP directed to the self. Rejection $(\beta=0.17, p<0.05)$, assumptions about straight people's attitudes toward homosexuality $(\beta=0.17, p<0.01)$, and IHP directed to the self $(\beta=0.15, p<0.05)$ were found to make significant and independent contributions to the explained variance in parental justification $\left(r^{2}=0.12, p<0.001\right)$.

There was also a significant correlation between rejection and parental burden. Lesbian mothers who experienced more rejection also felt more burdened by the child. In addition, rejection was also significantly correlated with parental competence. Lesbian mothers who experienced more rejection also felt themselves less competent as a parent. The other aspects of minority stress and parental burden were not related, nor were there significant associations between these other dimensions and parental competence.

Minority stress and child adjustment. Table 2 also shows correlations between minority stress and the mother's report of child adjustment. Lesbian mother's experiences with rejection was the only minority stress variable that was significantly related to child adjustment (see Table 2). Lesbian mothers who reported more experiences with rejection reported higher levels of children's externalizing and internalizing behaviour problems and also reported higher levels of children's total number of problems. No significant associations were found between the other aspects of minority stress and child adjustment.

\section{Discussion}

To explore diversity among lesbian families, the present study examined several dimensions of minority stress, and the relationship of minority stress with experiences 
of parenthood and child adjustment. The lesbian mothers in this sample generally reported low levels of rejection, perceived stigma, and internalized homophobia. In spite of the low levels of minority stress, higher levels of rejection were, as expected, associated with more sense of parental stress and more sense to justify the quality of the parent-child relationship. Having negative assumptions about straight people's attitudes toward homosexuality, and having higher levels of internalized homophobia, were also associated with more parental justification. Levels of rejection were associated with more emotional/behavioural problems in children.

Some of the relationships we expected to find were not supported by the findings. There is, for example, no support for the idea that perceived stigma and internalized homophobia led to more parental stress (parental burden and parental incompetence). Lesbian mothers' levels of perceived stigma and internalized homophobia also did not lead to less adjustment among the children. Other aspects that are not related to lesbian parenthood and minority stress, of course, would be more related to parental stress and child adjustment. It has been shown that mothers with high workload, with more children in the family, or mothers who perceived their child as fussy/difficult report more parental stress (Österber \& Hagekull, 2000). Such aspects were not include in our study, because the purpose of the study was to analyse the impact of factors that are related to minority stress.

Before discussing and interpreting the results, it should be mentioned that the low levels of minority stress experienced by lesbian mothers in the present study may be explained by the relatively positive climate regarding to homosexuality in the Netherlands (Sandfort, 1998; Waaldijk, 1993; Widmer et al., 1998). Lower levels of social acceptance of homosexuality include higher levels of rejection, and therefore the observed level of negative treatment might be greater in other Western countries than in the Netherlands. Furthermore, it might be that due to the decision to become a mother within a lesbian relationship, participants in the present study were probably higher in self-acceptance than many other lesbians. Morris et al. (2002), for example, found that lesbians who had children before coming out were more likely to have ever had mental health counselling than those who had children after coming out.

One should also bear in mind that the educational level of participants in this study is relatively high. On the other hand, several studies have shown that lesbian women tend to be more highly educated (Flaks et al., 1995; Johnson et al., 1994; McCandlish, 1987; Patterson, 1994; Sandfort, 1998; Steckel, 1987). It seems that children from lesbian low-SES mother families are more likely than those from middle-class lesbian mother families to experience peer stigma about issues related to the lesbian identity of the mother (Tasker \& Golombok, 1997).

Other studies on minority stress show that experiences with discrimination and violence are major roadblocks to well-being for many lesbians (Garnets et al., 1990; Herek et al., 1999). Negative reflection from others might be internalized and might lead to uncertainty towards how to cope with being a mother in a non-traditional family. Garnets et al. (1990) described the psychological mechanism that could explain the effect of discrimination, and violence on well-being among lesbian women. According to Garnets and her colleagues (1990), victimization interferes with perception of the world as meaningful and orderly. Lesbian women who have experienced negative treatment try to restore order to their perception of the world and often respond with self-devaluation. This psychological mechanism might also explain the associations between minority stress, especially negative treatment, and parental justification and parent's report of child adjustment. Emotional/behavioural 
problems in children may be more determined by factors that are not related at all with growing up in a lesbian family. In several studies it was found that the psychological adjustment of children in planned lesbian families did not differ from children in a two-parent heterosexual family (Golombok, 2001). In our study, however, we studied differences within planned lesbian families and our results suggest that minority stress indeed may have a negative impact on mothers and children.

From anecdotal stories and interview studies, it is known that the main concerns of lesbian women who are thinking about getting children are the possible negative implications of raising a child in a non-traditional family in a heterosexist and homophobic society (Gartrell et al., 1996; Leiblum et al., 1995; Weeks et al., 2001). Lesbian women are concerned about their children's possible disadvantage in their relationships outside the family caused by the prejudice they would encounter from their peers (Touroni \& Coyle, 2002). However, research conducted among young adults who grew up in a lesbian mother family in the United Kingdom has found that as children they were no more likely than the children of a heterosexual mother to have been teased or bullied by peers (Golombok, 2000; Tasker \& Golombok, 1997). Vanfraussen et al. (2002) reported that children in lesbian families were not frequently more teased than children in heterosexual families in terms of their clothes, and physical appearance; however, family-related incidents of teasing were only mentioned by children from lesbian families. It would be interesting to examine how children themselves in planned lesbian families cope with being a member of a minority group.

Limitation to the present study is that some of the scales were used for the first time in a study among lesbian mothers and have not been validated yet for this specific group. Furthermore, since we relied on self-report, it could be that some measures, such as negative experiences and child adjustment, are affected by a tendency of lesbian mothers to give socially desirable answers. As a consequence, some of the perceptions of the respondents might not accurately reflect the actual situation. Finally, the design used in this study was cross-sectional, which implies that one has to be cautious in interpreting the causal direction of the established relationships.

The present study is one of the first studies on lesbian parenthood to examine the relationship between minority stress and parental experience of parenthood and child adjustment. It is also the largest study to date of lesbian families. Our findings underscore the importance of the effect of minority stress on the lives of lesbian mothers and their children. Health care providers working with lesbian families, but also teachers with children from lesbian mothers in the classroom, should appreciate the effect of minority stress and should learn to support coping in dealing with minority stress. On the other hand, granting legal rights and respect to lesbian parents and their children should lessen the stigma some of them now suffer. In that case it is necessary to pay attention to the level of societal acceptance of planned lesbian families as a critical factor that can either facilitate or disrupt the successful adaptation of children in these families.

\section{Acknowledgements}

The data for this article were collected as part of a research project on parenting in lesbian families, which was supported by the Netherlands Organization for Scientific Research (NWO). 


\section{References}

Achenbach, T.M. (1991). Manual for the child behaviour checklist/4-18. Burlington, VT: University of Vermont Department of Psychiatry.

Bos, H.M.W. \& SANDForT, TH.G.M. (1999). Homoseksuele mannen en vrouwen over hun werksituatie. 'De prijs die ik betaal'. Zoetermeer: ABVAKABO FNV.

Brewaeys, A., Ponjaert, I., Van Hall, E.V. \& Golombok, S. (1997). Donor insemination: child development \& family functioning in lesbian mother families with 4 to 8 year old children. Human Reproduction, 12, 1349-1359.

Brooks, V. (1981). Minority stress and lesbian women. Lexington, MA: Lexington Books, D.C. Health.

Crnic, K.A., Greenberg, M.T., Ragozin, A.S., Robinson, M.M. \& Basham, R.B. (1983). Effects of stress and social support on mothers and premature and full-term infants. Child Development, 54, $209-217$.

DE GRAAF, H. \& SANDForT, TH. (2001). De maatschappelijke positie van homoseksuele mannen en lesbische vrouwen (The position of gay men and lesbian women in Dutch society). Utrecht: RNG.

DiPlacido, J. (1998). Minority stress among lesbians, gay men, and bisexuals: a consequence of heterosexism, homophobia, and stigmatization. In: G.M. Herek (Ed.), Stigma and sexual orientation. Understanding prejudice against lesbians, gay men, and bisexuals: psychological perspectives on lesbian and gay issues, Vol.4, pp. 138-159. Thousand Oaks, CA: Sage.

Flaks, D.K., Ficher, I., Masterpasqua, F. \& Joseph, G. (1995). Lesbian choosing motherhood: a comparative study o lesbian and heterosexual parents and their children. Developmental Psychology, 31, 105-114.

Garnets, L., Herek, G.M. \& Levy, B. (1990). Violence and victimization of lesbians and gay men: mental health consequences. Fournal of Interpersonal Violence, 5, 366-383.

Gartrell, N., Hamilton, J., Banks, A., Mosbacher, D., Reed, N., Sparks, C.H. \& Bishop, H. (1996). The national lesbian family study: interviews with prospective mothers. American fournal of Orthopsychiatry, 66, 272-281.

Goffman, E. (1963). Stigma: notes on the management of spoiled identity. New York: Simon and Schuster.

GolomboK, S. (2000). Parenting: what really counts? London: Routledge.

Golombok, S., Tasker, F.L. \& Murray, C. (1997). Children raised in fatherless families from infancy: family relationships and the socioemotional development of children of lesbian and single heterosexual mothers. Fournal of Child Psychology and Psychiatry, and Allied Disciplines, 38, 783-791.

Golombok, S., Perry, B., Burston, A., Golding, J., Murray, C., Mooney-Somers, J. \& Stevens, M. (2003). Children with lesbian parents: a community study. Developmental Psychology, 39, 20-33.

HereK, G.M. \& GLunT, E.K. (1995). Identity and community among gay and bisexual men in the AIDS era: preliminary findings from the Sacramento men's health study. In: G. M. HEREK \& B. GreENE (Eds), AIDS, identity, and community, pp. 55-84. Thousand Oaks, CA: Sage.

Herek, G.M., Cogan, J.C., Gillis, J.R. \& Glunt, E.K. (1997). Correlates of internalized homophobia in a community samples of lesbians and gay men. Fournal of the Gay and Lesbian Medical Association, 2, 17-25.

Herek, G.M., Gillis, J.R. \& Cogan, J.C. (1999). Psychological sequelae of hate-crime victimization among lesbian, gay, and bisexual adults. Fournal of Consulting and Clinical Psychology, 67, 945-951.

Hubert, A.B. (1996). Mobbing, pestgedrag op de werkplak: een exploratief onderzoek. Leiden: Rijksuniversiteit.

Johnson, A.M., Wadsworth, J., Wellings, K. \& Field, J. (Eds) (1994). Sexual attitudes and lifestyles. Oxford: Blackwell Scientific.

KaEser, P. \& Gillespie, G. (1999). Loves makes a family: portraits of lesbian, gay, bisexual, and transgender parents and their families. Amherst: University of Massachusetts Press.

KING, B.R. \& BLACK, K.N. (1999). College students' perceptual stigmatization of the children of lesbian mothers. American fournal of Orthopsychiatry, 69, 220-227.

Leiblum, S.R., Palmer, M.G. \& Spector, I.P. (1995). Non-traditional mothers: single heterosexual/lesbian women and lesbian couples electing motherhood via donor insemination. Fournal of Psychosomatic Obstetrics and Gynaecology, 16, 11-20.

LEYMANN, H. (1990). Mobbing and psychological terror at workplaces. Violence and Victims, 5, 119-126.

MaYs, V.M. \& Cochran, S.D. (2001). Mental health correlates of perceived discrimination among lesbian, gay, and bisexual adults in the United States. American fournal of Public Health, 91, 1869-1876.

McCandlish, B. (1987). Against all odds: lesbian mothers family dynamics. In: F. BozeTt (Ed.), Gay and lesbian parents, pp. 23-38. New York: Praeger.

Meyer, I.H. (1995). Minority stress and mental health in gay men. Fournal of Health and Social Behavior, 36, 38-56.

Meyer, I.H. (2003a). Prejudice, social stress, and mental health in lesbian, gay, and bisexual populations: conceptual issues and research evidence. Psychological Bulletin, 129, 674-697. 
Meyer, I.H. (2003b). Prejudice as stress: conceptual and measurement problems. American fournal of Public Health, 93, 262-265.

Morningstar, B. (1999). Lesbian parents: understanding development pathways. In: J. LAIRD (Ed.), Lesbians and lesbian families: reflection on theory and practice, pp. 213-241. New York: Columbia University Press.

Morris, J.F., Balsam, K.F. \& Rothblum, E.D. (2002). Lesbian and bisexual mothers and nonmothers: demographics and the coming-out process. Fournal of Family Psychology, 16, 144-156.

Nungesser, L.G. (1983). Homosexual acts, actors, and identities. New York: Praeger.

Östberg, M. \& Hagekull, B. (2000). A structural modelling approach to the understanding of parenting stress. Fournal of Clinical Child Psychology, 29, 615-625.

Patterson, C.J. (1994). Children of the lesbian baby boom: behavioral adjustment, self-concepts, and sexrole identity. In: B. Greene \& G. Herek (Eds), Psychological perspectives on lesbian and gay issues: Vol. 1. Lesbian and gay psychology: theory, research, and clinical applications, pp. 156-175. Thousand Oaks, CA: Sage.

Patterson, C.J. (1995). Families of the lesbian baby boom: parents' division of labor and children's adjustment. Developmental Psychology, 31, 115-123.

Patterson, C.J. (2001). Families of the lesbian baby boom: maternal mental health and child adjustment. In: D.F. Glazer \& J. Drescher (Eds), Gay and lesbian parenting, pp.91-108. New York: Haworth Press.

Robbroeckx, L.M.H. \& Wels, P.M.A. (1989). Nijmeegse vragenlijst voor de opvoedingssituatie (NVOS) (Nijmegen questionnaire regarding child-rearing circumstances). Nijmegen: Instituut voor orthopedagogiek, katholieke Universiteit Nijmegen.

Ross, M.W. \& Rosser, B.R. (1996). Measurement and correlates of internalized homophobia: a factor analytic study. Fournal of Clinical Psychology, 52, 15-21.

Rothuizen, J. (2001). Lesbisch ouderschap (Lesbian parenting). In: K.A.P.DE Bruin \& M. BALKema (Eds), Liever vrouwen. Theorie en praktijk van de lesbisch-specifieke hulpverlening, pp. 119-136. Amsterdam: Schorer Boeken.

SANDFort, TH.G.M. (1997). Samen of Apart. Wat homoseksuele mannen en lesbische vrouwen beweegt (Together or separate. Aspects that affects gay men and lesbian women). Utrecht: Utrecht University, Department of Gay and Lesbian Studies.

SAndfort, Th.G.M. (1998). Homosexual and bisexual behaviour in European countries. In: M. HUBERT, N. Bajos \& Th.G.M. SANDForT (Eds), Sexual behaviour and HIVIAIDS in Europe, pp. 68-106. London: UCL Press.

SANDFort, TH.G.M. (2000). Homosexuality, psychology, and gay, lesbian studies. In: Th.G.M SANDFORT, J. Schuyf, J.W. Duyvendak \& J. Weeks (Eds), Lesbian and gay studies: an introductory, interdisciplinary approach, pp. 14-45. London: Sage.

SAndfort, Th.G.M. \& Bos, H. (2000). Being open at work. Paper presented at APA congres 2000.

SANDFort, Th.G.M., Bos, H. \& Vet, R. (in press). Lesbians and gay men at work: consequences of being out. In: A.M. Омото \& H.S. Kurtzman (Eds), Sexual orientation, mental health, and substance use: contemporary scientific perspectives. London: Sage.

Seyda, B. \& Herrrera, D. (1998). Women in love: portraits of lesbian mothers and their families. Boston: Bulfinch Press Book.

SHIDLO, A. (1994). Internalized homophobia: conceptual and empirical issues in measurement. In: B. Greene \& G. HereK (Eds), Psychological perspectives on lesbian and gay issues: Vol. 1. Lesbian and gay psychology: theory, research, and clinical applications, pp. 176-205. Thousand Oaks, CA: Sage.

Slater, S. (1999). The lesbian family life cycle. Chicago: University of Illinois Press.

STECKel, A. (1987). Psychological development of children of lesbian mothers. In: F.W. BozetT (Ed.), Gay and lesbian parents, pp. 75-85. New York: Praeger.

Szymanski, D.M., Chung, B. \& BAlsam, K.F. (2001). Psychosocial correlates of internalized homophobia in lesbians. Measurement and Evaluation in Counselling and Development, 34, 27-38.

TAsker, F.L. \& Golombok, S. (1997). Growing up in a lesbian family: effects on child development. London: Guilford Press.

Touroni, E. \& Coyle, A. (2002). Decision-making in planned lesbian parenting: an interpretative phenomenological analysis. Fournal of Community and Applied Social Psychology, 12, 194-209.

VAn de Meerendonk, B. \& Scheepers, P. (in press). Denial of equal rights for lesbians and gay men. Accepted for publication in the fournal of Homosexuality.

Van der Avort, A., Cuyvers, P. \& De Hoog, K. (1996). Het Nederlandse gezinsleven aan het eind van de twintigste eeuw (Dutch family live at the end of the 20th century). Den Haag: Nederlandse Gezinsraad. 
Vanfraussen, K., Ponjaert-Kristoffersen, I. \& Brewaeys, A. (2002). What does it mean for youngster to grow up in a lesbian family created by means of donor insemination? Fournal of Reproductive and Infant Psychology, 20, 237-252.

Verhulst, F., van Den Ende, J. \& Koot, H. (1996). Manual for the Dutch version of the child behaviour checklist/4-18. Rotterdam: University of Rotterdam, Department of Child Psychiatry.

WAALDIJK, K. (1993). The legal situation in the member states. In: K. WAALWIJK \& A. Clapham (Eds), Homosexuality: a European community issue, pp. 130-138. Dordrecht: Martinus Nijhoff.

WALDO, C.R. (1999). Working in a majority context: a structural model of heterosexism as minority stress in the workplace. Fournal of Counselling Psychology, 46, 218-232.

Warmerdam, H. \& GoRT, A. (1998). Meer dan gewenst. Handboek voor lesbische en homoseksuele ouders (More than wished for. Handbook for lesbian and gay parents). Amsterdam: Schorer Boeken.

Weeks, J., Heaphy, B. \& Donovan, C. (2001). Sam-sex intimacies: families of choice and other life experiments. London: Routledge.

Weinraub, M. \& Wolf, B. (1983). Effects of stress and social supports and two-parent families. Child Development, 54, 1297-1311.

Wels, P.M.A. \& Robbroeckx, L.M.H. (1991). Gezinsbelasting en hulpverlening aan gezinnen II, de constructie van de Nijmeegse vragenlijst voor opvoedingssituatie (Family stress and family counselling II, the construction of the Nijmegen questionnaire regarding child-rearing circumstances). Tijdschrift voor Orthopedagogiek, 30, 63-79.

WERnER, E.E. \& SMITH, R.S. (1982). Vulnerable but invincible: a longitudinal study of resilient children and youth. New York: McGraw Hill.

Widmer, E.D., Treas, J. \& Newcomb, R. (1998). Attitudes toward non-marital sex in 24 countries. fournal of Sex Research, 35, 349-358. 


\section{Authors Queries}

Journal: Journal of Reproductive and Infant Psychology

Title: Minority stress, experience of parenthood and child adjustment in lesbian families

Authors: H.M.W. BOS ET $\boldsymbol{A L}$.

Dear Author

During the preparation of your manuscript for publication, the questions listed below have arisen. Please attend to these matters and return this form with your proof. Many thanks for your assistance

\begin{tabular}{|l|l|l|}
\hline $\begin{array}{l}\text { Query } \\
\text { Reference }\end{array}$ & Query & Remarks \\
\hline $\mathbf{1}$ & Meyer 2003a or 2003b? & \\
\hline
\end{tabular}

